\title{
Kin Support and the English Poor: evidence from
}

\author{
Lancashire, c. 1620-1710*
}

\section{Abstract}

The 'nuclear hardship bypothesis', argued by Peter Laslett in 1988, holds that that the prevalence of the nuclear household in early modern England, and the apparent weakness of kinship interactions outside it, left the burden of caring for the vulnerable squarely on the 'collectivity', most obviously in the form of the Elizabethan Poor Law. But recent studies of family and kinship in English society have questioned the idea of the autonomous nuclear household, challenging us to reconsider this notion from the perspective of the early modern poor. This article uses a largely untapped set of sources, pauper petitions, to look for qualitative evidence of kinship support amongst the seventeenth-century English poor. Focusing on the county of Lancashire, mines petitions for references to kinship support, to the forms it took, and to what it 'meant' to recipients. It argues that kinship support was not uncommon, and indeed was the expected social norm where it was physically available. But it had clear limits, and might only be a temporary expedient; moreover, most recorded examples saw support flowing between former members of the same nuclear household.

\footnotetext{
* The author is extremely grateful for the useful comments from all three reviewers for Historical Research, and to participants in the Local History Seminar at Kellogg College, Oxford, for their discussion of a version of this paper. Martin Ingram and Leigh Shaw-Taylor both commented on very early drafts.
} 
The nature of the relationship between kin in pre-modern England has been an area of some debate. ${ }^{1}$ On the one hand, historians such as Peter Laslett, Keith Wrightson and Alan Macfarlane have argued for minimal interaction between relatives outside the immediate nuclear household. ${ }^{2}$ Computerized demographic modelling, meanwhile, has suggested that the numbers of kin 'available' to the average ordinary man or woman were fairly small. ${ }^{3}$ On the other hand, scholars such as Miranda Chaytor, David Cressy, and Naomi Tadmor, have pointed to important - if often fleeting - ties of mutual support between kin, whilst also arguing for more flexibility and fluidity in household structures. ${ }^{4}$ Historians of the nineteenth century, meanwhile, qualifying the bald primacy of the nuclear household suggested in census returns, have found evidence of residential propinquity between kin, or suggested that many kinship relationships have been hidden by the source material and only come to light in detailed community reconstructions. ${ }^{5}$ The wider availability of sources for later periods has allowed historians to construct a contrasting picture of occasional, fluid, but fundamentally meaningful and important relationships between kin.

This is an issue of obvious social historical significance, but that significance gains an extra dimension when considering the poor. In a 1988 article, Laslett suggested that the predominance of the autonomous nuclear household had important implications for the development of English social policy in the early modern period. To Laslett, '[n] early everything we know as yet about kinship in 
England indicates "loose" kin relations." The 'potential value', he said, 'of the wider kin network as an insurance against misfortune, a resource which could have been tapped by most people on many occasions even if it was finally unreliable for their sustained support, seems to have been of little or no significance'. ${ }^{7}$ This meant that the burden of care for the poor and the vulnerable fell on what Laslett called the 'collectivity'. In England, this collective support was, as a result of the Tudor Poor Laws, largely channelled through local taxation. Thus the primacy of the nuclear household, and the weakness of kin relations, can be taken as a major reason why England developed what was, by Continental standards, an unusually organized system of formal poor relief from the late sixteenth century onwards, namely one that depended on taxation and redistributive spending, and which was - by the end of the seventeenth century - expending something like $£ 400,000$ a year, nationally, on the poor. ${ }^{8}$ This was the 'nuclear-hardship hypothesis'.

Such an argument makes sense if we accept the idea that poor households were small, inflexible, and isolated from their kin. Evidence from the occasional censuses of the poor that are extant from the sixteenth and seventeenth centuries does support this, showing small average household sizes amongst the poor. ${ }^{9}$ Nonetheless, scholars of later periods have emphasized quite strongly the continued importance of kin networks to the support of the poor as part of a wide-ranging, complex and diverse 'economy of makeshifts' that gave some cushion between the poor and total dependence on the parish. ${ }^{10}$ Thus, Thomas Sokoll found exactly the kind of residential fluidity amongst the poor that Laslett 
largely discounted, and which allowed kin to play a major role in the support of the poor and (especially) the aged. ${ }^{11}$ Steven King, writing on the poor of the early nineteenth century, made a similar point, finding the flexibility of pauper households to be a 'consistent theme whatever the socio-economic or life-cycle circumstances of the paupers concerned'. ${ }^{12}$ Indeed, this flexibility was specifically encouraged by poor law authorities who deliberately remodelled the living arrangements of the elderly and who engaged in a 'traffic in children', often between related households. ${ }^{13}$ The same author found evidence for the usefulness of proximate kin in an earlier study of Calverley in the West Riding, while Sam Barrett, also looking at the woollen district of the same county, found there was in practice, in expectation and in rhetoric, a considerable role for kinship support in the economy of makeshifts and in addition to the poor law'. ${ }^{14}$ The nineteenth century evidence certainly has become harder to square with the notion of the autonomous nuclear household.

We should be careful of reading evidence backwards from later periods. Population growth and eventually falling mortality rates meant that people in the later eighteenth and nineteenth centuries will have had more living kin than their ancestors. Because of the earlier age at marriage and thus younger childbearing, a nineteenth century widow would have had more useful kin because her children and grandchildren were older than would have been the case in the seventeenth century.${ }^{15}$ Nonetheless, studies of earlier periods have often hinted at the potential importance of kin support to the poor. The 1601 poor law statute theoretically 
made vertical kin (except grandchildren) directly responsible supporting their poor relatives:

the father and grandfather, and the mother and grandmother, and the children, of everie poore olde blinde lame and impotent person, or other poore person not able to worke, beinge of a sufficient abilitie, shall at their owne chardges releive and mantaine everie such poore person...

Indeed, JPs did enforce this, though apparently relatively rarely. ${ }^{16}$ Laslett himself found that - in six household listings between 1599 and 1796 - nearly half of aged couples (60 years and over) had offspring living with them, presumably to help with their care. ${ }^{17}$ This fits with a view, recently summarised by Richard Wall, that whereas for much of the time, kinship interactions were weak, 'there is also evidence of very significant support from family members in some circumstances: by children living with their widowed mothers, for example, or in some cases from children and other relatives living elsewhere' ${ }^{18}$ In the rare cases where this support can be quantified, it does seem to have been quite considerable. In the case of widows supported by children, for example, in the nine such households in Ipswich in 1597, 65 per cent of earnings were provided by children; in six households in Salisbury in 1637 the equivalent figure was 48 per cent, and in nine Corfe Castle households in 1790 it was 89 per cent. ${ }^{19}$ More recently, Sheila Cooper has argued that historians of kinship need to be sensitive to the powerful emotional force that kin relations still had. 'English people', she argues, 'responded very extensively to the needs of kin, broadly defined, as well as to their future security'. More to the point, she argues, 'social norms would have been violated had they not 
done so'. ${ }^{20}$ Although early-modernists do not have the kind of evidence that is available for later periods, it would appear that relations between the poor and their kin may have been more complex, perhaps stronger, than a hardline reading of Laslett's 'nuclear hardship hypothesis' would allow.

One of the major problems with reconstructing the kin relationships of the poor is the paucity of usable source material. Much of the work arguing against the isolation of English people from their kin has relied on narrative sources, such as diaries and letters. By their nature, such sources rarely relate to the poor, at least until the late eighteenth and early nineteenth centuries when we start to get the pauper letters used to such effect by King and others. Nonetheless, some narrative sources do exist. Jeremy Boulton, for example, used pauper examinations from the West End of London, dating to the early eighteenth century, to look at the 'survival strategies' of the poor. He specifically looked at the stories of support told by paupers, and found considerable evidence of kinship support - both vertical and horizontal - particularly flowing downwards, from older people to younger. ${ }^{21}$ Sheila Cooper, more recently, provides one example of diary written by someone relatively poor: the rather singular case of Edward Barlow, a poor Lancastrian who migrated in the late seventeenth century to London - where he made use of kin networks - before going to sea. ${ }^{22}$ 
Of course, Barlow was hardly typical, but there are other narrative, and semi-narrative, sources which might also be used to good effect. Depositions in criminal and regulatory court cases, for example, occasionally show ordinary people engaging in mutual relationships with their kin, such as the two brothers, their 'kinswoman', and another relative involved in a burglary in York in 1628. Or, the 40-year-old St Albans woman who was victim to an attempted rape by one Thomas Wells in 1629 but 'did cry out for helpe, and thereuppon her sister being present took him by the leg and drew him away from her. ${ }^{23}$ The process of extracting kin interactions from these courtroom tales will be laborious, but it may well prove illuminating.

Another, perhaps even richer kind of source, are petitions for aid of one sort or another. Petitioning as a whole in the medieval and early modern period is now beginning to attract considerable attention, and it is increasingly recognized as a major element of the popular politics of the age, though there are still relatively few published studies. ${ }^{24}$ The pioneering work on petitioning by the poor has been that of Steve Hindle, whose influential 2004 monograph, On the Parish?, made systematic use of the excellent archive of pauper petitions for the county of Cumberland, dating from 1686 to $1749 .{ }^{25}$ These, he pointed out, allowed the historian to 'hear vivid tales of ongoing filial duty and sacrifice'. Many of them involved 'relatives well beyond the narrow range of lineal kin stipulated in welfare legislation'. 'When these petitions are read against the grain', Hindle suggests, 'it is 
possible to identify an otherwise invisible network of kin solidarity through which informal support was provided'.

Hindle, though, was only able to look at a relatively small number of petitions as part of a much wider project. His approach, though, has considerable potential, and it is this that is developed here. In the Lancashire there exist many thousands of petitions to the county's magistrates, sitting in Quarter Sessions. They are archived by sessions (Quarter Sessions met four times a year each in four separate locations: Lancaster, Preston, Wigan/Ormskirk, and Manchester), and cover a wide range of administrative business, including the management of the poor law. From the 1620s up to around 1710 many - perhaps most - of poor law petitions originated in appeals against decisions on individual relief cases, by parishes and townships. In some cases petitions were generated in what were possibly relatively controversial cases, where the township officers supported the petitioner's claim, but for some reason wanted ratification from the magistracy. Usually, though, petitions were written on behalf of someone who had applied for relief to their township, but had been refused, and were appealing the decision to Quarter Sessions. They thus represented a crucial political tool for the poor, representative of their 'agency' within the poor law system. It is not always possible to tell whether petitions were successful, but so far as can be gleaned from detailed archival work, appeals were rarely refused outright. Nonetheless, in some cases, townships dragged their heels in implementing a relief order, or themselves challenged the decision with a counter-petition. In archival terms, this means that a 
proportion of petitions relate to cases that were already active at Quarter Sessions. These have been excluded from this study, as to include them would bias the sample towards the more controversial cases. Thus, of around 5,000 surviving petitions asking for poor relief (and excluding those petitioning for a habitation or disputing a settlement), some 3,169 have been identified as 'first petitions', i.e. the initial appeal to Quarter Sessions. I have read all of these, and extracted information from them into a database. They cover the whole of the county, though with rather less coverage of the area north of Morecambe Bay (in presentday Cumbria). The bulk of the sample date from after the Civil War, though 171 do survive from before 1642. There are peaks during bad harvest years (1637, $1650,1657-62,1674-5,1699)$.

The documents followed an identifiable form, common to many early modern petitions, and discussed by Peter Jones and Steven King. ${ }^{26}$ They began with a salutation, usually 'To His Majesty's Justices of the Peace of the General Sessions of the Peace...' or something similar. Then, adopting a tone of humility, they would then recount the name, location, and perhaps age and certain characteristics of the lead petitioner. Following from this, they would narrate the causes that petitioner had to need poor relief, ending with an appeal for support, and usually a humble offer to pray for the benevolent magistrates in question. Just occasionally they added some statement about the social justice of the claim: asking for relief 'as law requireth', for example, or such relief 'as may stand with justice and equitie and as is usual in such cases'. ${ }^{27}$ The core information for our purposes 
is contained within the middle section, i.e. the narrative. Most of this was dedicated to a description of why the petitioner had come to be poor, but sometimes that story included incidental details about attempts to stave off dependency by participating in what we have come to call the 'economy of makeshifts'. To give a rather vivid example, the following is the core section of the petition, dated 13 April 1662, of Thomas Nailor of Standish.

Sheweth, That your petitioner being about three score $\&$ ten yeares of age, formerly lived in good \& credible condition, but aboute foure yeares since it pleased God to visit him with an ague \& other sore sicknes, which continued on him aboute three yeares, in which time all his estate $\&$ meanes was spent, \& consumed, \& likewise being stricken with a palsie, soe that all his right side is uselesse, he now lyeth in a miserable condition not able to helpe himselfe in any thinge, his very bed being all rotten under him by reason of a lasket that hath houlden him above three yeares, \& his impotencie not being able to move himselfe: in this lamentable condition he is like to perish, unless some releefe be granted for him, for being destitute of both meanes \& able frends to releeve him, he for a longe time this winter hath had noethinge but what pittifull neighbours have sent him, and likewise none are willing to be trobled to looke to him, \& helpe him in this his loathsome condition, onely a kinswoman of his hath out of naturall affection thus far beene with him, but she beinge of small estate unable to releeve him \& greeveinge to see his dayly miserie is discoraged \& almost wearied out. ${ }^{28}$

Thus Nailor details his descent into poverty through sickness and old age, but he also talks about having spent his estate before asking for relief. Crucially, he also commented on the help he was receiving from elsewhere. He had nothing but what 'pittifull neighbours' brought him; he had no 'able frends to releeve him',

† Diarrhoea. 
except that a 'kinswoman' had been looking after him, he said, out of 'naturall affection'. Although this is a sorrowful tale of poverty and illness, Nailor's petition is also telling us something about the availability of kin support, and about its social meaning.

Not all elements of these petitions are suitable for quantification. Petitioners were expected to state the reasons for their poverty, and nearly all did. Of the 3,169 petitions, some 43 per cent mentioned the principal's old age or stated they were aged 50 or over; 50 per cent mentioned sickness or disability; 40 per cent mentioned being single (usually widows, reflecting the gendered nature of poverty, but also including widowers, spinsters, abandoned wives and two abandoned husbands). Some 43 per cent mentioned children, although since some included children they had raised rather than those still living in, this should not be taken as an indication of family size at the time of petitioning. A rather smaller proportion, 4 per cent, mentioned unemployment, high prices, small wages, or similar. Just over half of lead petitioners were female.

The trouble comes when we want to quantify references to strategies of 'making shift'. There are plenty of such references in petitions, but unlike references to the causes of poverty, there was no expectation that the petitioner would include such information. In fact, there was something of a disincentive. Where they did describe such strategies, it was to say they had been exhausted or were not viable in the first place, such as Thomas Nailor's assertion that he had no 'able frends', and that his generous kinswoman was 'almost wearied out'. This 
article, then, will use quantification very carefully: it is not proposed that the fleeting statements in petitions provide a basis for quantifying the extent of kin support amongst the Lancashire poor, although comparing mentions of different kinds of support might be useful (though the ambiguity of the term 'friends', which could refer to kin or to friends in the modern sense, is another stumbling block). ${ }^{29}$ Instead, the focus will be on the narratives in the petitions, and the approach will be largely qualitative. This allows us to consider stories about kin support generated by the poor themselves, but it still leaves us with two questions: are the narratives reliable, and are they representative?

Of course, 'reliability' is hard to gauge, and it depends on which kind of historical 'truth' we are looking for. Petitions were instrumental documents, aimed at eliciting a sympathetic response. Clearly they are thus open to exaggeration, even outright falsehoods. That said, three elements to their production might give us more confidence. Firstly, petitioners were not simply producing statements to the court independent of anyone else's input. As most of them would have been illiterate or semi-literate, they would have had to get a neighbour to write their petition for them. Some of these scribes will have been paid, but others still will have done the job as a form of charity; as the scribe had greater indifference to the outcome of the petition, their input could have acted as a stop on the most egregious falsehoods. Thus, while scribal input might lead us to be cautious when describing these sources as a 'voice of the poor', it might also provide some kind of check on factual accuracy. Moreover, many petitions were actually endorsed by 
neighbours, sometimes individuals (including clergy and local gentry), and sometimes long lists of these are appended to the petitions. ${ }^{30}$ Again, this acted as a check on the petitioner's claims. Secondly, petitioners were generally, it seems, expected to present their appeal directly to the court themselves: they were thus subject to examination. One petitioner, for example, wrote that he and his family really were 'objects of charity as to your worships will appeare when they are called to the barr' ${ }^{31}$ The reference to being called to the bar of the court suggests he was expecting some level of examination. Another petitioner even brought his four young children to the sessions, 'to shew them to your worshipps' as proof of his need. ${ }^{32}$ Thirdly, all petitions were subject to appeal by aggrieved townships. In most cases there were no such appeals once an initial order had been made, though there is sometimes evidence for a certain amount of foot-dragging by reluctant townships. On the other hand, we know that officers sometimes attended sessions (or paid attorneys to do so), so the potential for hostile questioning or appeal was real. This will have been an incentive to keep as far possible to verifiable statements, or at least to those which could not be disproved. Moreover, any claims made to the magistracy had to be within the bounds of easy believability, so at the very least they represent 'discourses of deservingness' - believable fictions whether those discourses were grounded in immediate reality or not. ${ }^{33}$

The second question, then, is representativeness. Although Lancashire has a large volume of surviving petitions, these only represent a minority of decisions about poor relief. They are likely to represent the most marginal and controversial 
cases, usually where township officers had initially turned the petitioner down. Indeed, those who actually applied for formal relief from their township were only likely to be a subset within the wider category of those in poverty. Those needing formal relief tended to be those whose attempt to 'make shift' had failed. Troublingly, this might mean that petitioners with available kin were less likely to end up as petitioners, because they were unlikely to need formal poor relief in the first place, or they were more likely to, because when they applied they were more likely to be turned down (precisely because they had available kin). Unfortunately, this is simply intractable, and stands as another reason we should be wary of unquestioning quantification.

It is worth pointing out, indeed, that narrative sources like these have been used to good effect by historians of later periods trying to produce qualitative evidence for the 'economy of makeshifts'. Pauper letters, a source unusual to the eighteenth and early nineteenth centuries, have been used in similar ways to those we might deploy petitions. ${ }^{34}$ Of course, the distance in time, their origin as letters between locations relating to the non-settled (usually therefore migrant) poor, and not least their very different epistolary structure means we cannot simply transpose lessons from the study of pauper letters to petitions. Scholarship on pauper letters has emphasized rather strongly that, although they were influenced by an earlier culture of petitioning, their composition and function was very different. This was a point made by Thomas Sokoll in 2006 and which has been re-emphasized in a recent chapter by Peter Jones and Steven King. ${ }^{35}$ Crucially, to Jones and King, 
letters included an element of 'shared discourse' between different 'actors in the relief process' which they consider absent in petitions. ${ }^{36}$ Thus, whereas petitions had a reasonably simple set of outcomes (usually a yes or a no), letters were 'part of an on going conversation' ${ }^{37}$ This all said, there is now an extensive literature on pauper letters from the later eighteenth and nineteenth centuries, some of which speaks directly to issues of kinship. As with petitions, letters often described proximate causes of hardship, attempts at 'making shift' in order to stave off dependency, as well as giving clues to rhetorical strategies employed by those in poverty when dealing with the authorities. Given the vivid insights provided by those working on later letters, and given the richness of the narratives provided by the earlier petitions (albeit within a tighter compositional form), it would be amiss for historians to ignore the valuable material contained in the latter.

This article attempts to analyse this material. It will work through a large corpus of pauper petitions, in order to recover what they say about the relationship between the poor and their kin. The petitions come from the historic county of Lancashire in north-west England, so the next section will describe Lancashire's economy, and discuss some of the evidence for family structure of the county's poor, as gleaned from census-type documents. Following on from this, the article will describe the evidence for kin interactions and support found in the thousands of pauper petitions that survive for the county. These will then be subjected to some basic quantitative analysis to see what kinds of kin relationships were represented in petitions. Something will then be said about the rhetoric of petitions 
to see if that can illuminate cultural meaning of kin support. Finally, the article will consider the other side of the coin, looking at evidence for the failure of kin support. The overarching theme is that, even though only a small minority of petitions mentioned kin support, there is clear evidence that it was important for at least some of the poor, although it seems to have been strongest between people who had at one time been part of the same nuclear household. There is also evidence from the rhetoric of petitions that support from one's kin carried important emotional weight; moreover, those petitioners who recorded the failure of kin support did so in such a way as to suggest that it was, where available, an expected social norm.

II

Lancashire was - in English terms - a relatively poor county. ${ }^{38}$ Its economy was not unsophisticated, and during the seventeenth century it was to develop in its south-eastern parts a prosperous and international textile industry (including the use of cotton fibre imported from the Levant). It also had a number of growing small towns, including the increasingly important port of Liverpool, and - in the Fylde - an arable region of some prosperity. In the south-west, a metalworking district was developing using local coal as fuel. But, compared to the agricultural heartlands of southern and midland England it remained relatively marginal. It was 
also relatively distant from the political centre, meaning that the poor law implanted itself quite slowly in the county, and through the seventeenth century it was spending rather less money per head of population than was the case further south. ${ }^{39}$ In part, this probably reflected a social structure that was rather more egalitarian than in the increasingly stratified south; it also - no doubt - had much to do with the dietary use of cheaper grains such as barley and oats. But it also suggests perhaps that formal poor relief may have been a smaller part of the 'economy of makeshifts' here than elsewhere. ${ }^{40}$ There may thus have been more need for kinship support and informal neighbourly charity.

The evidence we have for household size amongst the Lancashire poor fits closely with what we might expect from the notion of 'nuclear hardship'. In Bolton in 1674, the mean household size amongst the poor was 2.9, whereas in 1686 and 1699 it lay at 2.4 and 2.6 respectively. ${ }^{41}$ Other listings from the county suggest a similarly small household size: a list of 89 paupers in Farnworth in 1682 yields a mean household size of 2.9, while a census of 301 poor in Colne in 1689 gives an equivalent figure of 3.7. ${ }^{42}$ Just outside the county, in the south Westmorland parishes of Grasmere and Windermere, lists of charity recipients in 1685 and 1687 give a similar picture, with an average household size of 3.0 and 2.8 respectively. ${ }^{43}$ Of these, only the Bolton censuses have enough detail of actual household composition to gauge whether complex types existed. The picture from here, though, is fairly straightforward: according to King, in the three census years, complex households never accounted for more than 10 per cent of recorded units. 
Looking more closely at the detailed censuses of 1686 and 1699 broadly supports this picture. ${ }^{44}$ In 1686, there are a recorded 42 single adults over 60 years old. None are counted within the households of adult kin, though five had young children or grandchildren listed with them. A more detailed sense can be gained from a census of 1699, which again reveals 42 households of single older people. Of these, Nicholas Pinks lived with his sister, while 80-year-old Roger Hardman lived with his 50-year-old daughter. The latter was described as 'melancholy' herself, so it is not quite clear exactly who was caring for whom; perhaps, indeed, the care was reciprocal - we should not assume that care just flowed one way. Of the remaining 40, two had young children living with them. Intriguingly, nine were described as 'sojourners' or 'tablers', often recorded as paying rent. Presumably these were being boarded out at the township's expense, and some may have been sent out to their kin, but the key conclusion is that the majority of Bolton's aged poor lived alone, and many of those who did not were tabled for rent. Whatever the later evidence, this suggests nuclear hardship.

There is an intriguing possibility, however, raised by King in an earlier study of the Bolton censuses, that powerful kinship links existed across household boundaries. In 1674, for example, King found that the pauper Ralph Boxwirth lived with his wife and three small children, next-door to one widow Margaret Boxwirth, 80 years old and also poor. It seems a strong possibility, given the unusual surname, that they were related. They did not live in the same household, so far as the overseers were concerned, but it is hard to imagine that there was not 
some form of mutually supportive relationship at play, again highlighting the importance of proximity to kin, as well as co-residence. ${ }^{45}$ Moreover, it is quite possible that some of the children reported in the census were orphans who had been taken in by kin: such relationships would not necessarily be apparent to later historians.

It is possible, in fact, that Lancastrians might have had more kin available than contemporaries in other areas. Will Coster, for example, suggests that pastoral farming areas with large commons - like much of Lancashire - were likely to see rather less out-migration and thus retain stronger communities of kin. ${ }^{46} \mathrm{He}$ also suggested stronger kinship densities in proto-industrial communities, a descriptor that could apply to much of the south and east (and arguably the south west) of the county. ${ }^{47}$ In the northern reaches of the county, the high level of surname clustering does hint at strong kinship networks (while also making them effectively impossible to measure). Further south, meanwhile, industrialization may have helped create a strong network of available kin, as fewer people were forced to move out in search of work. ${ }^{48}$ The jury remains out, and specific evidence for the seventeenth century is lacking, but it seems plausible to suppose that Lancastrians may well have had stronger local links with their kin than those living further south. On the other hand, microsimulation exercises have pointed to the historically low kinship availability in the demographic conditions of the late seventeenth century. It has been calculated that a man born in 1650 could expect to have had 1.9 live children when he reached 65 , and 2.8 grandchildren, whereas a 
man born a century later would have on average 2.6 children and 5.7

grandchildren. ${ }^{49}$ Thus even if Lancashire might have had unusually high levels of kin availability, the demographic conditions of the later seventeenth century work the other way. It is simply not possible at present to say whether such factors have resulted in significant source biases. It remains, then, to consider what the petitions tell us about kinship support in seventeenth century Lancashire.

III

It is clear, from reading the corpus of Lancashire petitions, that some at least amongst the poor were supported by members of their kin network. Charles Holt of Tottington, for example, in a petition of 1676, told Manchester magistrates that he (and presumably his wife) 'hath beene supplied by their charitable relacions'. ${ }^{50}$ There are a number of references to support by 'friends'. Often, though, the importance of kin support was expressed in the negative. Petitioners would state that one of the reasons they needed poor relief was that they had no kin or 'friends' to relieve them. For example, a 23-year-old petitioner, Jennet Formby (of Formby) stated in 1656 that she had 'few frends or kinred', while a similar phrase was deployed at Lancaster sessions in 1678, when Esther Townson, a lame woman of the town, complained that she had not any 'friend or kindsman att all able to give her anything. ${ }^{51}$ Widow Ellen Gorton of Aspull, meanwhile, perhaps with one 
eye on statute law, petitioned that her child Robert 'is not able to gett his livinge and hath noe friends, nor Grandfather or grandmother able to releeve him'. ${ }^{52}$ Such statements - although they highlight a lack of available kin in many cases, an issue to which we will return - show a basic assumption that kin support was at least desirable. Presumably in part this was a reflection of petitioners' legal literacy: they knew that magistrates would be looking keenly for relatives to take the burden away from the township: emphasizing the lack of kin would forestall this. But this should not be taken as evidence that kin support was a mere ideal, to be invoked when it was politically useful, for other petitioners gave specific details about support they had actually received.

Petitions show mutual support continuing between parents and children once the latter had left home. Anne Robinson, for example, a Lancaster warwidow, found herself relying in 1658 on her father's support into her own old age, petitioning for parish support when he died leaving no estate. ${ }^{53}$ In 1657 James Byrom of Hundersfield, whose trade as a woollen-webster had decayed, recounted to Manchester justices that 'had not his aged father Comiserated his condition and over charged himselfe in relieveing of their wants your petitioner his wife and children had beene enforced to have turned vagrant or otherwise to have starved.${ }^{54}$ Support could flow the other way too, with adult children looking after their ageing or infirm parents. In 1675, Edward Bond of Hornby told Lancaster JPs that he was maintaining five children and 'an ancient woman' (he was referring to his mother) ${ }^{55}$ Richard Molyneaux, a saltworker from Prescot, was - he 
petitioned in 1631 - 90 years old, and had spent all his means since the onset of his impotency. This had left him chargeable to those of his children 'that had wherewithall to releeve hime'. ${ }^{56}$ In Lydiate, Alice Blacoe told of how she was 80 years old, 'not able to goe to any neighbours house by reason of her impotency', but that her daughter had 'laboured in the country for her reliefe'. ${ }^{57}$ Jennet Bannister of Hornby helped her sick, octogenarian mother by carrying her petition to Lancaster Sessions for her in $1636 .^{58}$ Alice Hartley reported how she supported her mother in her old age: she 'not onely begged for her', she told Preston magistrates in 1660, 'but borrowed monies in severall places'. ${ }^{59}$ In 1628, Anne Read of Ditton, who was 97 years old, widowed, blind and lame, had for two years been supported by her son. ${ }^{60}$ In 1693, Ellin Copland of Blackrod described how she had been relieved by her children, though they were no longer able to do so. ${ }^{61}$ Mary Smith of Caton was, in 1658, being helped by her son-in-law. ${ }^{62}$

Where they survived, grandparents could also give support in times of hardship. Christopher Mouldin, a labourer from Whittingham, asked magistrates at Preston for money to make the trip to London so one of his three children could be touched for the King's Evil. The child had, he noted, had hitherto been maintained by its grandmother. ${ }^{63}$ Young Elizabeth Whitehead of Walton-le-Dale, meanwhile, evidently an orphan in 1664, was similarly harboured by her grandmother. ${ }^{64}$ On the other hand, unlike the case with parents and children, it is much less common to see support flowing from grandchildren to grandparents. Statute law allowed the authorities to force parents and grandparents to support 
their children and grandchildren; they could also force children to pay for their parents, but there was no such provision for grandchildren to be made to support their grandparents. Presumably the generational difference here meant that there were few enough children of independent means with surviving grandparents who needed aid. Some manner of such support, however, is shown in the case of Lettice Gleast of Fazakerly, a petitioner to Wigan sessions in 1661. Blind and 72 years of age, Lettice had lost her husband - run away, she said, 'as is presumed for debt'. Her infirmity had left her unable to 'travell amongst her neighbours to crave their charitable alms', though - she noted - 'a grand child doth daily beg for her releefe'. ${ }^{65}$

Adult siblings sometimes supported one another. In 1652, Preston magistrates were presented with the petition of Edmund Sudell of Fishwick, a webster struck blind the previous May, and who was now 'forced to entreate his brother which is a poore workeman to lead him from dore to dore to gett a livelyhood'. ${ }^{66}$ In 1654, Margaret Banister of Ashton near Lancaster recounted how she was sick and 'hath wasted both her sisters substance and her owne in seekinge for remedie'. ${ }^{67}$ In 1669, the husband of Anne Hoggard of Thornton, now a prisoner, had - according to Anne's petition - been supporting his two sisters as well as his own household. ${ }^{68}$ In at least one case there is a hint that this fraternal support had specifically been enforced by parish authorities (notwithstanding the fact that statute law placed the burden on vertical and not horizontal kin). Ellen Hesketh, a spinster of Scarisbrick had lived in London, where she fell sick. She was 
sent back to Scarisbrick, on which journey the hapless Ellen broke her leg, so that she could be maintained by her brother; he was - she said - unable to look after her. ${ }^{69}$

In some petitions it is clear that support entailed kin actually living together. Financial support did not just flow between related nuclear households: those nuclear households were themselves sometimes flexible enough to remodel themselves to take in vulnerable relatives. In Heath Charnock in 1634, husbandman Richard Shorrock, so he petitioned, was looking after his mother, she 'beinge in house with him'. ${ }^{70}$ In 1676, Thomas Williamson of Ashton-in-Makerfield petitioned that he had a family of five children but also that his mother, 90 years old, lame and blind was living with them. ${ }^{71}$ When Nicholas Bray, vicar of St Michael's-on-Wyre died around 1650, he left 'many small children' without a father. One of them, Elizabeth, was fourteen at the time and may well already have been suffering from the falling sickness that was to afflict her later teens. She lived with her mother for three years in Catterall, but then - with her mother unable to maintain her - she was sent as a sojourner with her brother William Bray for nine years. But her health had deteriorated yet more, and had been sent back again to her mother. ${ }^{72}$ This said, in most cases co-residence was not mentioned. As most descriptions of support were quite vague (it has not, for example, been possible to quantify types of support in the way Boulton did for the West End) $)^{73}$, we cannot put too much on this. However, it seems likely given the relative silence of the 
sources that most support flowed between households that were physically separated.

The overall picture, then, is clear. Children and parents, and brothers and sisters, are reported to have supported one another, even once they no longer lived together. Children could be maintained by their parents long into late adulthood. More distant relationships can be found too. In these cases at least, kin support mattered.

\section{IV}

The analysis so far has been resolutely qualitative, and this is deliberate. But there are some insights that can be gained from a brief quantitative analysis of mentions of kin support. The actual proportion of petitions that recounted such support was small, but given that there was no expectation it should have been mentioned, and given the fact there may even have been a disincentive to mention it, this is not surprising. It may also be the case that those who had available kin did not need poor relief and thus did not need to petition (though equally, perhaps they were more likely to be refused at first appeal). What is perhaps more important to note, though, is that kinship support was referenced less frequently than the support of neighbours. Barry Reay has cautioned us (at least for the nineteenth century) about drawing rigid distinctions between 'kin' and 'community', on the grounds that many people in his study villages in Kent had large numbers of kin within their 
community. ${ }^{74}$ Nonetheless, except where the ambiguous term 'friends' is used, petitioners do appear to make some distinction between kin and neighbour. Adopting a wide definition to include references to 'friends', there are 118 petitions out of the 3,169 which make positive mention of kinship support (i.e. excluding those that specifically say it was not available), representing 3.7 per cent of the total sample. By comparison, I have identified some 217 petitions which mention neighbourly support, or 6.8 per cent of the total. And this is to say nothing of the substantial number of petitions which mentioned begging. Of those 118 , there is little sense that they are quantitatively different in character to the total sample. Some 49 per cent of them referred to being old, 47 per cent sick, and 39 per cent in 'broken' households (abandoned, widowed, or otherwise single). This compares to 43 per cent old, 50 per cent sick, and 40 per cent single in the whole sample. The differences are marginal, though the slightly higher proportion of aged is perhaps interesting. If we abstract the 118 petitions by Quarter Sessions sitting (i.e. as a proxy for region), Lancaster sessions is over-represented (21.2 per cent of the kinship sample versus 13.7 per cent of the total), whereas Manchester is under-represented (20.3 per cent versus 31.7 per cent). If anything, then, the evidence for kinship support is slightly stronger in the northern part of the county than the industrializing south. ${ }^{75}$

Perhaps the most interesting quantitative finding relates to the kinds of kin who were found giving support. One petitioner, Edward Scorer invoked a wide network of potential support, albeit in the negative. He had, he said, neither 
'parentes, uncles, auntes, brother, sister, or any of his kinne now living to relye upon'. ${ }^{76}$ In reality, though, most known cases refer to help flowing between parents and children, and between siblings. Within the 118 petitions, there are 86 specific descriptions of kinship support. Of these, seventeen involved parents supporting grown-up children, thirteen saw support by brothers and three support by sisters (including one sister-in-law). Three saw grandmothers supporting grandchildren, and there is one example of a grandfather who did so. Two cases are reported of support by uncles, one by an aunt, one by a cousin, one by a nephew and another by a nephew's husband (sic). Overall, the most frequentlymentioned supportive relationship involved children giving support to their parents, of which there were 43 cases. This stands in marked contrast to Boulton's findings for the West End of London, in 1708-9, in which most recorded support flowed downwards, and hardly any did upwards. ${ }^{77}$ Perhaps most striking, though, is that 76 out of the 86 cases ( 88 percent) saw support flowing between siblings or between parents and children. We should be a little careful with these data - the fact that support between parents, grandparents, and children could be enforced perhaps encouraged petitioners to emphasise the fact it was not available, and thus - usefully for historians - actually mentioning it. But this does all seem to suggest perhaps paradoxically - that where support existed beyond the immediate nuclear household, it tended to flow between kin who were formerly members of the same nuclear household. Does this reflect the emotional bonds forged by co-residence, or was their greater moral obligation between close relatives? Perhaps both. ${ }^{78}$ 
Petitions also give us a sense of what such support might actually mean to both givers and recipients. Looking closely at their language can shine at least some light at the culture of affection and mutuality that underpinned people's support for their poor kin. This is an aspect of the petitions that needs to be considered with due care, as what we are looking at are rhetorical strategies rather than necessarily meaningful descriptions of actual emotions. As noted earlier, petitions were rarely actually written by the pauper themselves so the scribe acted as a cultural filter. Nonetheless, it is unlikely the pauper had no input, nor should we assume the cultural environment of the petitions' scribes was particularly different to the petitioners themselves. Petitions were not purely scribal documents; they should be seen as speaking with a hybrid voice.

For what it is worth, the language used in petitions suggests that kinship support was based on fairly deep-seated emotional ties. One of the earliest surviving petitions, from 1628, used the word 'compassion' to describe the reasons behind support. It was for the relief of an orphaned child, Daniel Dunster of Bury, who would - the petition stated - have starved 'but for the tender Compassion of some of his mothers frends' who 'did take him up from wanderinge because he was not able soe to doe'. ${ }^{79}$ Thomas Nailor of Standish, of course, we have already seen being helped by a kinswoman 'out of naturall affection' ${ }^{80}$ The most common 
sentiment, though, was 'love'. Jane Rigby of Eccleston, for example, reported in 1630 that she had 'growne to such impotencie that she cannot bee well kept without a woman to attend her', but that her brother, a cottager and webster, had maintained her 'of his brotherlie love towardes her'. ${ }^{81}$ In 1649, Anne Howsman of Lancaster, 90 years old 'and soe infirme that shee is not able to put on her cloathes much lesse seeke for reliefe', had nothing to support her 'unles it bee the charitie and benevolence of her neighbours \& loving friends etc' ${ }^{82}$ The son of Alice Copland, a 90-year-old woman of Longton, petitioned on her behalf to Ormskirk sessions in 1662 , saying that he had maintained her 'out of charitie \& love', though he now had no estate but a cottage, and five children of his own to look to. ${ }^{83}$ Jane Parke, a 15-year-old girl from Out Rawcliffe, described in 1675 how she had lost both her parents and suffered herself from the palsy, but that her uncle had helped her out of 'love \& respecte'. ${ }^{84}$ The discourse here is one of altruism, but altruism could of course include an element of exchange, and on at least one occasion an exchange relationship was explicitly described, here with parents explicitly saying they raised their children in the hope they would care for them in old age. James Gettings, a cook from Hornby petitioned in 1659 that he and his wife had 'twoe sonnes whome he and his poore wife tenderly brought up and nourished and dearely loved in hope that they should have had comforth in them and help from them in this their decrepit ould age'. ${ }^{85}$ Alas, politics intervened, and they left to fight in Scotland during the wars, and they never came back. 
To be fair, there are hints of similar emotional expectations of neighbours. It was 'out of there tender affection' that some of the 'good neighbours' of lame Ellen Sutch of Burscough procured her 'some lodging and granted her some small reliefe forth out of the parish' in the period leading up to $1661 .{ }^{86}$ The same year, Humphrey Leathwaite and his wife of Ainsdale recounted how they would have had 'utterly perished' had they not been relieved by the 'tender affection of their good neighbours'. ${ }^{87}$ But the language of charity was more often deployed when describing neighbourly support, something which becomes especially curious when it is recalled that 'charity' and 'love' could be broadly synonymous in the early modern period. One of the earliest surviving petitions, that for Jennet Clarke of Caton in 1629, tells of how she was helped by 'the charitable almes of good neighbours' when her husband was pressed as a soldier. ${ }^{88}$ Or twenty years later, when the Smalshaw children of Ormskirk were supported by their grandmother, who petitioned on their behalf, but who were also helped by 'the charity of well affected neighbours' ${ }^{89}$ Peter Smith of North Meols, 'exceeding old', lame and almost blind in 1653, had no income save 'the charitable releive of good people'. ${ }^{90}$ In 1662, Christopher Townson of Over Wyresdale, who was 97, told - in a petition perhaps tellingly endorsed by his neighbours - of how dimness of sight had left him unable 'to goe from house to house amongst his good and Charitable neighbours as formerly he hath done who hath hitherto liberally releived your poor petitioner.' ${ }^{91}$ 
'Benevolence' was another word often associated with neighbourly support. Catherine Mawdsley of Ormskirk, 'striken in years', had nothing to live on but 'the benevolence of good people'. ${ }^{92}$ Other neighbours showed compassion or godliness. Elizabeth Scofield, a lame spinster from Tottington near Manchester, 'fatherlesse \& motherlesse', had - she petitioned in 1630 - nothing to live by but 'the Charitable helpe of good and godlye Christians' ${ }^{93}$ Eighty-year-old Katherine Stringfellow of Windle was, in 1651, 'inforced to begg amongst her neighbours which shee is not able to doe but that they in Cristian Charitie doe send reliffe to your petitioners house. ${ }^{94}$ It was godliness, too that Thomas Clifford, a Warrington labourer, evoked in his 1669 petition, recalling how his sick family would have starved "had it not beene that the lord hath stird up some of neighbors harts to relieve us'. ${ }^{95}$ Thus, charity, benevolence, and godliness were all concepts applied to neighbourly assistance. But kin support, it seems, might have been different. In petitions, kin support was based on 'love'.

\section{VI}

It is the nature of the sources that they usually describe kinship support after it had been exhausted or ended. Thus, the petitions quoted earlier which show an expectation of kinship support were it available, can also be used to make the obvious point that - in many cases - it was not. In some cases, for example, useful kin were simply too distant to be much use. Thomasine Wood of Withington, for example, 
told Manchester JPs in 1657 that her husband had run away, leaving her with four children to look after, and that her 'good friends' were 'far off. ${ }^{96}$ Four years later Ormskirk magistrates heard the case of Rachel Molleneaux's children, whose mother was in gaol as a result of a dispute over her right of dower, and who had their petition stated - come over from Ireland, and hence had no nearby friends. ${ }^{97}$ This is not to say that support could not flow over long distances: Edward Steele, an old woollen-webster from Pilkington, recounted in 1667 how he had 'had 2 sones which lived in London who were a greate stay unto theire father but were taken in the last visitation'; the Great Plague of 1665, in other words. He was, he petitioned 'left very desolate'. ${ }^{98}$ But though this was fine in theory, support from those kin who lived at a distance is bound to have been harder to draw upon.

Even where kin were nearby, they might themselves be poor and thus unable to support their destitute relatives. A petition to Ormskirk Sessions by the Ministers and Elders of Warrington Classis on behalf of William Cowper, presented in 1647 , noted that William - a former soldier - was poor and lame, and that 'his freinds being poore' they were 'not able to releeve him' ${ }^{99}$ Fifteen years later, spinster Jane Tarleton of Hesketh asked for relief from Ormskirk JPs, lamenting how her 'poore friends' had 'already extended their hands of charity towards her farr beyond their Abilityes'. ${ }^{100}$ Richard Smith has pointed out that at the very point that many Englishmen and women were reaching old age, their children were likely to be having to support their own families. ${ }^{101}$ Bryan Byrom, a 90-year-old pauper of Windle in the south-west of the county suffered from just 
such an intergenerational coincidence. He had grown lame and blind, he petitioned in 1654, and were it not for his son maintaining him 'hee had like to have starved', but 'nowe his sonn is married and is scarse able to mantayne his one [own] charge', let alone his ageing father. ${ }^{102}$ Similarly, in 1671 William Houghton of Eccleston told magistrates at Wigan that

he hath beene hitherto releeved \& manteyned by the industry \& handy labour of John Houghton his sonne but your petitioners said sonne hath a wife and two little Children haveinge noe estate but what by his owne labour $\&$ dayly worke hee getteth is much depaupered \& very poore \& not able further to manteyne or releelfe his aforesaid father. ${ }^{103}$

Indeed, marriage and the raising of children was not the only moment in the lifecycle that the burden of poor relatives might prove too much. Ellen Barron of West Leigh petitioned in 1652 that she was old, blind and thus destitute, especially now that her 'chyld kinfolkes' had now gone into service. ${ }^{104}$ When parents lived into great old age, there was even the possibility that their own children would start to suffer the infirmities of age themselves, such being the case with the octogenarian Thomas Crosby of Brownhurst in Eccles, who told Manchester JPs in 1657 that his daughter had been helping him, but that she too had now grown old. ${ }^{105}$ 
Nor could parents themselves live for ever. Twenty-three year-old Matthew Hughson of Warton-in-Amounderness told Preston JPs in 1658 that he was blind, but 'hitherto his late Father maintained him without trouble or charge to the Towne or Parish'. Sadly, however, 'his said carefull Father beinge lately deceased, his tenement out of lease and his personal Estate scarce sufficient to discharge his debts' and this was no longer a priority. ${ }^{106}$ Margery Martan's story was more complex. She was single and lame, but 'dureing her fathers life was maytayned by him'. He had died, however, and after his death she had been looked after by her brother, Robert Martan. Robert, though, was now married and 'hath a charg of children \& soe hath turned your petitioner out of doores, but her good neighbours doth releive hir'. ${ }^{107}$

Others described how they had been supported by relatives, only to overburden them, even pushing them into tricky water themselves. Margaret Clarkson of Elle, said she had in 1650 used up all her and her friends' means for the subsistence of herself and her children. ${ }^{108}$ Half a decade later, Ellin Law of Wheelton, 77 years old, lame and 'almost stone blind', recounted how she had, for three and half years, 'beene mainteyned by her daughter who hadd gotten some smale meanes in service', but 'with keeping your petitioner now quit[e] consumed the same'. ${ }^{109}$ And the following year, in 1656, Isabel Hey of Westhoughton told of how she was old, widowed and almost blind, and though she had been 'sustained by her o[w]ne worke and with the good helpe of her frends', these were now 'not soe willing neither soe able'. ${ }^{110}$ Agnes Lawson of Catterall recounted to Preston JPs 
in 1657 that, at 97 years, she was forced to hire a servant to help her to and from her own bed; she had been relieved by her son: 'A poore laboringe man who hath brought himselfe into much debt havinge a wife and three children'. ${ }^{111}$ Mary Hutchison of Newton told in 1674 of how she and her child, abandoned by her husband, had been maintained by her father but 'hee hath so mutch impoverished himselfe that hee is not able to mentaine them any longer'. ${ }^{112}$ Relatives and carers might themselves fall sick. Katherine Bannister of Cuerden, blind and widowed, was supported by her son, but when he became visited with sickness in 1657 she found herself petitioning magistrates at Wigan. ${ }^{113}$

Support in one or two cases fell off for more unusual reasons. In 1686, Agnes Harris of Whittington, an isolated township in the Lune Valley, reported that she was 'a very poore old woeman lame \& almost blind'. It seems she had been supported by her unmarried daughter, but now the assistance was gone, for her daughter was now 'in the custody of the master of the House of Correction \& haveing remained there ever since last sessions for the bearinge of a bastard child'. ${ }^{114}$ Elderly John and Ellen Robinson of Tatham in the north Lancashire Pennines, reported in 1668 that they had been relieved by their daughter, who had $£ 20$ a year, but that she had been 'forced to leave them'. ${ }^{115}$ They did not say why. Perhaps more common - particularly mid-century - was the experience of John Garnet, an old pauper of Gressingham. He and his wife had 'theire releife and maintenance' from their son, but some time before 1651 he had been conscripted as a soldier. ${ }^{116}$ Conscription, of course, brought obvious risks. Giles Hadwyn, a 
lame old man of Lancaster, described in 1656 how he had 'had his sonne slayne in the States service, which was a great losse to your petitioner'. ${ }^{317}$ This was also the case with James Gettings, whose children had gone to the wars in Scotland and never come back. ${ }^{118}$

In a few cases, indeed, petitioners complained of their relatives' failure to support them, or even that the actions of their kin had actually helped cause their poverty. Naomi Tadmor has called for historians to consider negative kin relations as much as positive ones, and there are several such examples in the Lancashire petitions. ${ }^{119}$ Thus, when Margaret Sharrock's husband, who had been 'a constant souldier under the said Parliament \& States servace ever since the warrs begain in England', was sent to fight in Ireland, she supported herself from her husband's plot of land in Standish. Unfortunately, however, her father-in-law had sold the tenement, leaving her poor and 'glad to begg their bread'. ${ }^{120}$ Elizabeth Penkethman, weak and widowed, of Newton-in-Makerfield, had been maintained by her eldest son, but sometime before her petition of 1661 he had left the county. ${ }^{121}$ William Wilkinson, an old blind pauper of Little Bolton, complained the following year of how he had possessed an estate of $f, 50$ per annum, but that he had alienated it to his daughter and son-in-law, they had promised to maintain him, but had now abandoned him. ${ }^{122}$ In 1669, meanwhile, Christopher Butler of Little Eccleston told Preston justices that he had been kept 'with the aid and assistance of his brother', but that now his brother 'doth altogether refuse to helpe or releeve him any longer'. ${ }^{123}$ Finally, one pauper even declared that she felt unable to beg for 
support because of how it might reflect upon her 'friends', including - it seems those beyond the grave. The 'moste of her friends beinge dead \& gone', Mary Kennison petitioned from Gorton in 1638, she was 'greately abashed \& dismayed to begg, for the disgrace of her friendes'. Perhaps the disgrace would have come from the fact Mary's begging would have announced to her neighbourhood that her living kin were not supporting the spinster in her old age.

In fact, there is a definite sense of bitterness towards some relatives who showed a lack of charity towards their kin which again suggests it was considered a significant social obligation. William Rawlinson of Chorley petitioned in 1659 that he had enjoyed an 'ancient and considerable estate', but that he had been denied access to it by his elder brother's 'wilful and wastful courses'. ${ }^{124}$ Elizabeth Cudworth, a 76-year-old widow from Moston who had suffered, she petitioned in 1661, 'severall great losses', told JPs that she 'haveinge formerly bestowed most of her substance uppon her sonne $\&$ his wife is nowe by them and their unnatural dealinge toward her enforced to leave her former habitacion and gett her relieffe out of the Charity of her neighbors'. They had, in other words, thrown her out of her own home. ${ }^{125}$ In 1674, Thomas France, a labourer from Lea, complained to Preston magistrates that his brother was 'rich' but was so parsimonious a man that 'hee would rather see him famished to death' than support him. ${ }^{126}$ A particularly striking and fascinating case, though, is that of John Rylough, an old, blind, lame and sick pauper from Heysham. He petitioned at nearby Lancaster in 1669 that he 
'heretofore lived in good order', not chargeable but 'rather helpfull to relieve others'. However, he lamented:

when his eldest sonne came to be a man your petitioner thought to[o] good of his said sonne [and] conveyed his whole estate to him and in consideration thereof was content to cast him selfe upon the care and providence of his said sonne who in a short time wasted and mortgaged all or the most part of the Estate aforesaid left his cuntrie and his ould Father your petitioner both sorrowfull and poore. ${ }^{127}$

It is an interesting story, because it would appear that some arrangement had been made to transfer property to a younger generation, who would then maintain an aged parent. Such agreements have been found in medieval England, but clearly in some cases they could go wrong, In this case, perhaps, the temptations of a quick windfall outweighed the pull of filial affection. ${ }^{128}$

Cumulatively, there is much evidence of the failure of kin support in Lancashire's petitions, but this - perhaps - is only what is to be expected. Petitioners were likely to be those whose circumstances had left them bereft of support, and even if they were not then they had an incentive to at least represent themselves in such a manner. Indeed, references to the lack of kinship support should be taken as evidence that such support was considered desirable, even normal. It was something on the minds of petitioners and their audiences; a clear 
social ideal. Although kin support was impermanent and, to an extent, on sufferance, the way petitioners described it - and the tangible bitterness expressed to those who willingly failed to play the part of kinsman - speaks to a cultural assumption that support should be offered where practical.

\section{VII}

In 1691, Ann Anderton of Heaton petitioned for poor relief at Manchester Sessions. She had five children, the eldest was eleven, and she had been widowed. In this dire poverty, she said, 'had not her friends and relations been more than ordinaryly kinde to her', she would not have 'subsisted this long without begging from door to door'. ${ }^{129}$ The question of what 'ordinary kindness' was expected between kin is an intractable one, and the problems of gauging it become even more pronounced when we look at the case of the poor. But the 'nuclear hardship hypothesis', which suggests that 'ordinary kindness' was limited, demands we keep asking it: the degree of isolation experienced by poor households is a crucial question.

This article has explored a relatively underused set of sources, pauper petitions, and looked in them for direct evidence of kin supporting each other through hard times. Such support is not hard to find; indeed, there is a sense in which it was an expected part of the 'economy of makeshifts' of the poor. Where it 
occurred, it was associated with feelings of 'love' and 'respect', as well as 'charity' (a word which at the time could often mean 'love'). Support came in a number of forms and was often in kind. The provision of board and lodging, which is the kind of support that might show up in censuses, was only one form.

But, as ever, the picture is one that needs careful qualification. Kinship support tended to flow between people who had once been part of the same nuclear household. By definition, meanwhile, the vast majority of the petitions studied here were specifically talking about the failure of kinship support. This does not mean that it always did - those cases where it did not might not have resulted in a petition; but it means that it did fail in enough cases for plenty of people to still need poor relief. Moreover, when they did mention being supported by others as part of their 'economy of makeshifts', they were more likely to mention support from unrelated neighbours, or - for that matter - begging, than that they were support from kin. And, at the end of it all, we are still faced with the nagging concern that, in Lancashire, we are looking at a society in which kin networks remained unusually strong and in which formal poor relief was late in developing and relatively low-spending. If we could find a similar archive of petitions for a southern county, then it is possible that a different picture might emerge.

Where does this leave the relationship between poor families and their kin in seventeenth century England? Ultimately, it is hard to argue with the notion of 'nuclear hardship'; the north-western European household was relatively isolated, and this did make life difficult for poor and vulnerable people. In turn, this did 
place a burden on the 'collectivity' for the support of many poor. But, at the same time, the stark picture given by census data does not do full justice to the small, fleeting, but critical flows of support between kin. This support was not available in all cases, nor could it go on indefinitely. But it was there, it could be a crucial safety-net, and it could have emotional resonance. There was, for many of Lancashire's poor, what Vern Bengston has called a 'latent kin network'. It could be inactive and unacknowledged for extensive periods, but it could kick decisively into action when an immediate crisis occurred. ${ }^{130}$ 
Table One: Sources of Kin Support in Lancashire Pauper Petitions, 16261710

\begin{tabular}{|l|l|l|}
\hline Nature of support & No. & $\%$ \\
\hline Parents supporting & 17 & 19.8 \\
\hline Children supporting & 43 & 50.0 \\
parents & & \\
\hline Support between siblings & 16 & 18.6 \\
\hline Grandparents supporting & 4 & 4.7 \\
\hline grandchildren & & \\
\hline Support by Aunts and & 3 & 3.5 \\
\hline Uncles & & 2.3 \\
\hline Support by Nephews & 2 & 1.2 \\
\hline Support by Cousins & 1 & - \\
\hline Total & 86 & \\
\hline
\end{tabular}


${ }^{1}$ Throughout this article, where an immediate domestic unit is being considered, the term 'household' has been preferred to 'family', because early modern households often included members, such as servants and apprentices, that we no longer consider 'family', and because most scholarship on 'nuclear hardship' has really focused on the household rather than the family as its basic unit. Where 'family structure' is mentioned, this is used in the wider sense of peoples' relationships not just with those they live amongst, but with those to whom they are closely related. 'Kin' is taken to refer to those considered as such, including blood relatives, affines, and 'fictive kin'. In fact, Peter Laslett repeatedly refers to the nuclear 'family', when technically he is referring to the 'household'. P. Laslett, 'Family, kinship and the collectivity as systems of support in pre-industrial Europe: a consideration of the "nuclear hardship" hypothesis', Continuity and Change, 3 (1988), pp. 153-75; studies of poverty on which this concept was influential include: T. Wales, 'Poverty, poor relief and the life-cycle: some evidence from seventeenth-century Norfolk', in R.M. Smith (ed.), Land, Kinship and Life-cycle (Cambridge, 1984), pp. 351-404; W. Newman-Brown, 'The receipt of poor relief and family structure: Aldenham, Hertfordshire, 1630-90', in Smith (ed.), Land, Kinship and Life-cycle, pp. 405-22; J. Healey, 'Poverty in an industrializing town: deserving hardship in Bolton, 1674-99', Social History, 35 (2010), pp. 125-47. ${ }^{2}$ P. Laslett, 'Mean household size in England since the sixteenth century', in P. Laslett and R. Wall (eds), Housebold and Family in Past Time (Cambridge, 1972), pp. 125-58; A. Macfarlane, The Family Life of Ralph Josselin, a Seventeenth-century Clergyman: 
an Essay in Historical Anthropology (Cambridge, 1970); A. Macfarlane, The Origins of English Individualism: the Family, Property and Social Transition (Oxford, 1978); K.

Wrightson, 'Kinship in an English village', in Smith, Land, Kinship and Life-Cycle, pp. 323-4; Laslett, 'Family, kinship and the collectivity'; K. Wrightson and D. Levine, Poverty and Piety in an English Village: Terling, 1525-1700 (2 ${ }^{\text {nd }}$ Ed., Oxford, 1995), pp. 91-99. On the role of non-blood relatives in the early modern household, see N. Tadmor, Family and Friends in Eighteenth-Century England: Household, Kinship and Patronage (Cambridge, 2000). Such household members are sometimes called 'fictive kin'.

${ }^{3}$ J.E. Smith and J.E. Oeppen, 'Estimating numbers of kin in historical England using demographic microsimulation', in D. Reher and R.S. Schofield (eds), Old and New Methods in Historical Demography (Oxford, 1993), pp. 302-17.

${ }^{4}$ M. Chaytor, 'Household and kinship: Ryton in the late sixteenth and early seventeenth centuries', History Workshop Journal, 10 (1980), pp. 25-60; D. Cressy, 'Kinship and kin interaction in early modern England', Past and Present, 113 (1986), pp. 38-69; D. O'Hara, 'Ruled by my friends: aspects of marriage in the diocese of Canterbury, c. 1540-1570', Continuity and Change, 6 (1991), pp. 9-41; N. Tadmor, 'The concept of the household family in eighteenth-century England', Past and Present, 151 (1996), pp. 111-40; Tadmor, Family and Friends; N. Tadmor, 'Early modern English kinship in the long run: reflections on continuity and change', Continuity and Change, 25 (2010), pp. 15-48; I.K. Ben-Amos, The Culture of Giving: 
Informal Support and Gift-Exchange in Early Modern England (Cambridge, 2008), pp. $47-58$.

${ }^{5} \mathrm{D}$. Mills, 'The residential propinquity of kin in a Cambridgeshire village, 1841', Journal of Historical Geography, 4 (1978), 265-78; M. Anderson, Family Structure in Nineteenth Century Lancashire (Cambridge, 1971); D. Cooper and M. Donald, 'Households and "hidden" kin in early nineteenth-century England: four case studies in suburban Exeter, 1821-1861', Continuity and Change, 10 (1995), pp. $257-$ 78; B. Reay, 'Kinship and neighbourhood in nineteenth-century rural England: the myth of the autonomous nuclear family', Joumal of Family History, 21 (1996), pp. 87104.

${ }^{6}$ Laslett, 'Family, kinship and the collectivity', p. 160.

${ }^{7}$ Ibid., p. 166.

${ }^{8}$ In a crowded field: P. Slack, Poverty and Policy in Tudor and Stuart England (London, 1988); S. Hindle, On the Parish? The Micro-Politics of Poor Relief in Rural England, 15501750 (Oxford, 2004).

${ }^{9}$ Slack, Poverty and Policy, p. 76

${ }^{10}$ See Hindle, On the Parish?, Part One; S. King and A. Tomkins (eds), The Poor in England: an Economy of Makeshifts (Manchester, 2003),

${ }^{11}$ T. Sokoll, 'The pauper household: small and simple?', Ethnologia Europaea, 17 (1987), pp. 25-42.

${ }^{12}$ S. King, 'The residential and familial arrangements of English pauper letter writers, 1800s-40s', in J. McEwan and P. Sharpe (eds), Accommodating Poverty: the 
Housing and Living Arrangements of the English Poor, c. 1600-1850 (Basingstoke, 2011), pp. 152-8; cf. S. King, 'The English proto-industrial family: old and new perspectives', History of the Family, 8 (2003), p. 33.

${ }^{13}$ Ibid, pp. 31-2, 34 .

${ }^{14}$ S. Barrett, 'Kinship, poor relief and the welfare process in early modern England' in King and Tomkins, The Poor in England, pp. 199-227, quotation at pp. 220-21. S. King, 'Reconstructing lives: the poor, the poor law and welfare in Calverley, 16501820', Social History, 22 (1997), pp. 318-38.

${ }^{15} \mathrm{R}$. Wall, 'Economic collaboration of family members within and beyond households in English society, 1600-2000', Continuity and Change, 25 (2011), p. 100. ${ }^{16}$ S.R. Ottaway, 'Providing for the Elderly in Eighteenth-Century England', Continuity and Change, 13 (1998), pp. 397-8.

${ }^{17}$ P. Laslett, Family Life and Illicit Love in Earlier Generations: Essays in Historical Sociology (Cambridge, 1977), p. 64.

${ }^{18}$ Wall, 'Economic collaboration', p. 99.

${ }^{19} \mathrm{Ibid}$, p. 91.

${ }^{20}$ S. Cooper, 'Kinship and welfare in early modern England: sometimes charity begins at home', in A. Borsay and P. Shapely (eds), Medicine, Charity and Mutual Aid: the Consumption of Health and Welfare in Britain, c. 1550-1950 (Aldershot, 2012), p. 55.

${ }^{21} \mathrm{~J}$. Boulton, “'It is extreme necessity that makes me do this": some "survival strategies" of pauper households in London's West End during the early 
eighteenth century', International Review of Social History, Supplement 8 (2000), pp. $56-64$

${ }^{22}$ Cooper, 'Kinship and welfare'.

${ }^{23}$ The National Archives, Northern Assize Depositions, ASSI 45/1/1/11-18;

London Metropolitan Archives, Diocese of London, Consistory Court, DL/C/322, pp. 21, 23

${ }^{24}$ Published studies include: J. Healey, 'Poverty, deservingness and popular politics: the contested relief of Agnes Braithwaite, 1701-06', Transactions of the Historic Society of Lancashire and Cheshire, 156 (2007), pp. 131-56; R.A. Houston, Peasant Petitions: Social Relations and Economic Life on Landed Estates, 1600-1850 (Basingstoke, 2014). ${ }^{25}$ Hindle, On the Parish?, pp. 48-58; also S. Hindle, "Without the cry of any neighbours": a Cumbrian family and the poor law authorities, c. 1690-1730', in H. H. Berry and E. Foyster (eds), The Family in Early Modern England (Cambridge, 2007), pp. 126-57.

${ }^{26} \mathrm{P}$. Jones and S. King, 'From petition to pauper letter: the development of an epistolary form', in P. Jones and S. King (eds), Obligation, Entitlement and Dispute under the English Poor Laws (Newcastle, 2015), pp. 53-77.

${ }^{27}$ LA, QSP/52/14; QSP/129/5; cf. QSP/197/15.

${ }^{28} \mathrm{LA}, \mathrm{QSP} / 223 / 19$.

${ }^{29}$ Jeremy Boulton came to a similar conclusion about the problems of quantification: Boulton, “It is Extreme Necessity”, p. 57. On 'friends': Tadmor, Family and Friends, pp. 145-7, 149-51, 167-92. 
${ }^{30}$ E.g. LA, QSP/79/25; QSP/122/19.

${ }^{31} \mathrm{LA}, \mathrm{QSP} / 832 / 43$.

${ }^{32} \mathrm{LA}, \mathrm{QSP} / 847 / 25$.

${ }^{33}$ Cf. N.Z. Davis, Fiction in the Archives: Pardon Tales and their Tellers in Sixteenth-century France (Cambridge, 1987).

${ }^{34}$ E.g. S. King, 'Friendship, Kinship and Belonging in the Letters of Urban Paupers, 1800-1840', Historical Social Research, 33 (2008), pp. $249-77$.

${ }^{35}$ T. Sokoll, 'Writing for relief: rhetoric in English pauper letters, 1800-1834', in A.

Gestrich, S. King and L. Raphael (eds), Being Poor in Modern Europe: Historical Perspectives, 1800-1940 (Oxford, 2006); Jones and King, 'From petition to pauper letter'.

${ }^{36}$ Jones and King, 'From petition to pauper letter', p. 73.

${ }^{37}$ Ibid, p. 76.

${ }^{38}$ On the economic history of Lancashire in the period: C.D. Phillips and J.H. Smith, Lancashire and Cheshire from AD 1540 (London, 1994); J.K. Walton, Lancashire: A Social History, 1558-1939 (Manchester, 1987).

${ }^{39}$ J. Healey, 'The Development of Poor Relief in Lancashire, c. 1598-1680', Historical Journal, 53 (2010), pp. 551-72.

${ }^{40}$ Cf. S. King, Poverty and Welfare in England, 1700-1850: A Regional Perspective (Manchester, 2000)

${ }^{41}$ Healey, 'Poverty in an industrializing town', p. 134. 
${ }^{42} \mathrm{LA}, \mathrm{DDKe} / 2 / 6 / 4$, Notes and Orders relating to the Poor of Deane, 1682; QSP/668/10, List of the Poor of Colne, 1689.

${ }^{43}$ Cumbria Record Office (Kendal Branch), WD/Ry/Box 35/1, Earl of Thanet's Charity, 1685 and 1687.

${ }^{44}$ The 1686 and 1699 censuses are in Bolton Archives and Local Studies, $\mathrm{PBO} / 1 / 1-2$, Bolton-le-Moors parish records.

${ }^{45}$ King, 'Locating and characterizing', pp. 56-8.

${ }^{46}$ W. Coster, Family and Kinship in England, 1450-1800 (London, 2001), p. 46.

${ }^{47}$ W. Coster, Kinship and Inheritance in Early Modern England: three Yorkshire parishes (York, 1993).

${ }^{48}$ Cf. S. King, 'Reconstructing lives: the poor, the poor law and welfare in Calverley, 1650-1820', Social History, 22 (1997), pp. 336-8.

${ }^{49}$ Smith and Oeppen, 'Estimating numbers'.

${ }^{50} \mathrm{LA}, \mathrm{QSP} / 453 / 7$.

${ }^{51}$ LA, QSP/155/16-17; QSP/478/9; for a similar cases, see QSP/127/15, QSP/149/1, QSP/425/25.

${ }^{52} \mathrm{LA}, \mathrm{QSP} / 55 / 19$.

${ }^{53} \mathrm{LA}, \mathrm{QSP} / 165 / 8$.

${ }^{54} \mathrm{LA}, \mathrm{QSP} / 144 / 30$.

${ }^{55} \mathrm{LA}, \mathrm{QSP} / 426 / 1$.

${ }^{56} \mathrm{LA}, \mathrm{QSB} / 1 / 86 / 59$.

${ }^{57} \mathrm{LA}, \mathrm{QSP} / 63 / 19$. 
${ }^{58} \mathrm{LA}, \mathrm{QSB} / 1 / 160 / 30$.

${ }^{59}$ LA, QSP/198/59.

${ }^{60} \mathrm{LA}, \mathrm{QSB} / 1 / 38 / 65$.

${ }^{61} \mathrm{LA}, \mathrm{QSP} / 739 / 24$.

${ }^{62} \mathrm{LA}, \mathrm{QSP} / 153 / 8$.

${ }^{63} \mathrm{LA}, \mathrm{QSP} / 330 / 16$.

${ }^{64} \mathrm{LA}, \mathrm{QSP} / 258 / 11$.

${ }^{65} \mathrm{LA}, \mathrm{QSP} / 215 / 23$.

${ }^{66} \mathrm{LA}, \mathrm{QSP} / 70 / 6$.

${ }^{67} \mathrm{LA}, \mathrm{QSP} / 101 / 4$.

${ }^{68} \mathrm{LA}, \mathrm{QSP} / 330 / 15$.

${ }^{69} \mathrm{LA}, \mathrm{QSP} / 191 / 11$.

${ }^{70} \mathrm{LA}, \mathrm{QSB} / 1 / 138 / 67$.

${ }^{71} \mathrm{LA}, \mathrm{QSP} / 444 / 42$.

${ }^{72} \mathrm{LA}, \mathrm{QSP} / 230 / 9$.

${ }^{73}$ Boulton, "It is Extreme Necessity", p. 59.

${ }^{74}$ Reay, 'Kinship and the Neighbourhood', p. 95.

${ }^{75}$ Cf. Anderson, Family Structure.

${ }^{76} \mathrm{LA}, \mathrm{QSB} / 1 / 134 / 60$.

${ }^{77}$ Boulton, “It is Extreme Necessity”, p. 62.

${ }^{78}$ For the limited importance of extended kin: Hindle, “Without the cry"”, p. 151.

${ }^{79} \mathrm{LA}, \mathrm{QSB} / 1 / 39 / 54$. 
${ }^{80}$ LA, QSP/223/19.

${ }^{81} \mathrm{LA}, \mathrm{QSB} / 1 / 78 / 62$.

${ }^{82}$ LA, QSP/21/12.

${ }^{83} \mathrm{LA}, \mathrm{QSP} / 227 / 17$.

${ }^{84} \mathrm{LA}, \mathrm{QSP} / 431 / 5$.

${ }^{85} \mathrm{LA}, \mathrm{QSP} / 177 / 1$.

${ }^{86} \mathrm{LA}, \mathrm{QSP} / 207 / 21$.

${ }^{87}$ LA, QSP/207/37.

${ }^{88} \mathrm{LA}, \mathrm{QSB} / 1 / 52 / 26$.

${ }^{89} \mathrm{LA}, \mathrm{QSP} / 11 / 25$; for similar cases see: QSB/1/265/32; QSP/180/22, QSP/207/5.

${ }^{90} \mathrm{LA}, \mathrm{QSP} / 83 / 6$.

${ }^{91} \mathrm{LA}, \mathrm{QSP} / 225 / 1$.

${ }^{92} \mathrm{LA}, \mathrm{QSP} / 480 / 13$.

${ }^{93} \mathrm{LA}, \mathrm{QSB} / 1 / 79 / 59$.

${ }^{94} \mathrm{LA}, \mathrm{QSP} / 43 / 41$.

${ }^{95} \mathrm{LA}, \mathrm{QSP} / 335 / 31$.

${ }^{96} \mathrm{LA}, \mathrm{QSP} / 144 / 20$.

${ }^{97} \mathrm{LA}, \mathrm{QSP} / 211 / 12$.

${ }^{98} \mathrm{LA}, \mathrm{QSP} / 312 / 25$.

${ }^{99} \mathrm{LA}, \mathrm{QSB} / 1 / 292 / 50$.

${ }^{100} \mathrm{LA}, \mathrm{QSP} / 223 / 1$. 
${ }^{101}$ R.M. Smith, 'The Structured Dependency of the Elderly as a Recent Development: Some Sceptical Historical Thoughts', Ageing and Society, 4 (1984), pp. 417-19; R.M. Smith, 'Ageing and Well-being in Early-modern England: Pension Trends and Gender Preferences under the English Old Poor Law, c. 1650-1800', in P. Johnson and P. Thane (eds), Old Age from Antiquity to Post-Modernity (London, 1998), p. 68.

${ }^{102} \mathrm{LA}, \mathrm{QSP} / 103 / 7$.

${ }^{103} \mathrm{LA}, \mathrm{QSP} / 363 / 15$, for similar cases see: QSP/450/7.

${ }^{104} \mathrm{LA}, \mathrm{QSP} / 71 / 1$.

${ }^{105} \mathrm{LA}, \mathrm{QSP} / 148 / 2$.

${ }^{106} \mathrm{LA}, \mathrm{QSP} / 154 / 1$.

${ }^{107} \mathrm{LA}, \mathrm{QSP} / 259 / 1$.

${ }^{108}$ LA, QSP/25/20.

${ }^{109}$ LA, QSP/107/3.

${ }^{110}$ LA, QSP/136/8.

${ }^{111}$ LA, QSP/138/17.

${ }^{112}$ LA, QSP/421/24.

${ }^{113}$ LA, QSP/151/13.

${ }^{114}$ LA, QSP/610/9.

${ }^{115} \mathrm{LA}, \mathrm{QSP} / 325 / 7$.

${ }^{116}$ LA, QSP/49/12.

${ }^{117}$ LA, QSP/129/2. 
${ }^{118} \mathrm{LA}, \mathrm{QSP} / 177 / 1$.

119 Tadmor, 'Early modern English kinship', pp. 27-28.

${ }^{120} \mathrm{LA}, \mathrm{QSP} / 31 / 19$.

${ }^{121}$ LA, QSP/203/28.

${ }^{122}$ LA, QSP/220/17.

${ }^{123} \mathrm{LA}, \mathrm{QSP} / 342 / 2$.

${ }^{124}$ LA, QSP/175/26.

${ }^{125}$ LA, QSP/204/17.

${ }^{126}$ LA, QSP/423/17.

${ }^{127} \mathrm{LA}, \mathrm{QSP} / 337 / 1$.

${ }^{128}$ E. Clark, 'Some aspects of social security in medieval England', Journal of Family History, 7 (1982), pp. 307-20; R.M. Smith, 'The manorial court and the elderly tenant in late medieval England', in M. Pelling and R. Smith (eds), Life, Death and the Elderly (London, 1991), pp. 36-61; P. Horden, 'Household Care and Informal Networks: Comparisons and Continuities from Antiquity to the Present', in P. Horden and R. Smith (eds), The Locus of Care: Families, Communities, Institutions and the Provision of Welfare since Antiquity (London, 1998), p. 43.

${ }^{129}$ LA, QSP/695/16.

${ }^{130}$ Vern L. Bengston, 'Beyond the nuclear family: the increasing importance of multigenerational bonds', Journal of Marriage and Family (2001), p. 12. 